\title{
The Pragmatics and Syntax of German Inalienable Possession Constructions
}

\author{
Vera Lee-Schoenfeld, ${ }^{1}$ Gabriele Diewald ${ }^{2}$ \\ University of Georgia, ${ }^{1}$ Leibniz Universität Hannover ${ }^{2}$
}

\section{The Phenomenon and Previous Syntactic/Pragmatic Analyses}

The prototypical inalienable possession construction in German has a dative (DAT)-marked external possessor:

$$
\begin{aligned}
& \text { Bello hat mir die Hand geleckt. } \\
& \text { Bello has me.DAT the hand licked } \\
& \text { 'Bello licked my hand.' }
\end{aligned}
$$

This is an instance of external possession because the understood possessor of the body part, the possessum, is expressed outside of the nominal phrase containing the possessum, showing up as an object pronoun ( $\mathrm{mir}$ ' $\mathrm{me}$.DAT) in the verbal argument domain. ${ }^{1}$ Notice that the literal translation of the dative does not work in English. This is because English generally prefers internal possessors and thus makes use of the possessive pronoun $m y$ rather than the object pronoun me in examples like (1) (see e.g. Haspelmath 2001, König and Gast 2012).

In German inalienable possession constructions with a PP-embedded possessum, there is considerable variation between the prototypical possessor dative construction and four others, so that there are a total of five different construction types: external possession with a dativemarked possessor (2a), external possession with an accusative (ACC)-marked possessor (2b), internal possession, with a genitive (GEN)-marked possessor (3), and doubly-marked possession, with both external and internal possessor, where the external possessor is again either dativemarked (4a) or accusative-marked (4b). ${ }^{2}$
a. Bello hat mir in die Hand gebissen. Bello has me.DAT in the hand bitten 'Bello bit me in the hand.'
b. Bello hat mich in die Hand gebissen. Bello has me.ACC in the hand bitten 'Bello bit me in the hand.'

1 For an overview of external possession constructions, see Payne and Barshi (1999) and Deal (to appear).

2 See Wegener (1985) for a thorough description of German external possession involving the dative case as well as the observation that dative and accusative can alternate in construction type (2). The case alternation has also been discussed by Hole (2005). 

Bello hat in meine Hand gebissen. ${ }^{3}$
Bello has in my hand bitten
'Bello bit in my hand.'
a. Bello hat mir in meine Hand gebissen.
Bello has me.DAT in my hand bitten
'Bello bit me in the hand.'
b. Bello hat mich in meine Hand gebissen. Bello has me.ACC in my hand bitten 'Bello bit me in the hand.'

Interestingly, when it comes to constructions with a PP-embedded possessum, English looks just like German in that it also makes use of external possession (see (2a-b)). According to König and Gast (2012:149), use of external possession in English is limited to constructions with adjunct PPs. The German construction types in (3) and (4) are less readily acceptable out of the blue (and are considered non-standard) but do not stand out as degraded if used in certain contexts or for certain purposes, as we will show in later sections. Before focusing on the marked constructions in (3) and (4), the remainder of this introduction discusses some prior positions concerning the case alternation in (2a-b).

As laid out in Lee-Schoenfeld (2012) and Lee-Schoenfeld and Diewald (2013), the case alternation in (2a-b) is found with verbs that allow a simple transitive valency frame (see (5)) as well as a directional one (see (6)). Commonly occurring examples of such verbs are beißen 'bite', schlagen/hauen 'hit', boxen 'box/punch', treten 'kick/step', and kneifen/zwicken 'pinch'.

Der Hund hat den Postboten gebissen.
the dog has the.ACC mailman bitten

'The dog bit the mailman.'

Der Hund hat ins Körbchen gebissen.
the dog has into.the basket bitten
'The dog bit into the basket.'

Crucially, with or without PP, these verbs have an inherent endpoint (are telic), and it is precisely the availability of the directional valency frame, i.e. the verb's intransitive use with a goal PP indicating the endpoint of the directed motion, that makes it possible to have a dative external possessor. The basic syntactic analysis of the dative/accusative case alternation in external possession constructions like (2) is summarized in Table 1.

3 The DP meine Hand 'my hand' as a whole is ACC-marked by the P in, but the $1^{\text {st }}$ person pronoun in Spec DP becomes the possessive pronoun mein- 'my' via GEN-marking. 
Table 1: Case-marking of external possessor with PP-embedded body part

\begin{tabular}{|c|c|l|}
\hline \multicolumn{2}{|c|}{ Option } & Constituent/Argument Structure \\
\hline (i) & $\begin{array}{c}\text { DAT-marked } \\
\text { possessor }\end{array}$ & $\begin{array}{l}\text { verb used intransitively with the PP as argument (i.e. the PP is } \\
\text { valency-based) }\end{array}$ \\
\hline (ii) & $\begin{array}{c}\text { ACC-marked } \\
\text { possessor }\end{array}$ & $\begin{array}{l}\text { verb used transitively, with the possessor as direct object and } \\
\text { the PP as adjunct (i.e. the PP is not valency-based) }\end{array}$ \\
\hline
\end{tabular}

Draye (1996) and Lamiroy and Delbecque (1998) propose an affectedness account of the dative/accusative case alternation in order to capture its pragmatic motivation. The claim is that the more "affected" the external possessor, the more likely it is accusative-marked. For a detailed discussion arguing against this claim, see Lee-Schoenfeld (2012). Here, we add to this discussion by pointing out that there are different uses of the term "affected", namely to mean (a) 'being directly acted upon or influenced, as opposed to being in control, not necessarily animate' (see e.g. Lehmann et al. 2004), i.e. having features of a typical patient versus (b) 'taking part in the situation as an empathetic, necessarily animate co-participant', i.e. sharing some features of a typical agent, without, however, being an agent because not having control (see e.g. Hole 2005, Lee-Schoenfeld 2006, 2007, McIntyre 2006, and Pylkkänen 2008). Given the use of "affected" with meaning (a), more affectedness should mean choice of accusative because (a) describes what is typical of the participant that is the verb's direct object, but given the use of "affected" with meaning (b), more affectedness should mean choice of dative because (b) describes what is typical of the participant that is the verb's indirect object (a recipient of bene/maleficiary). The next section will discuss the labeling of participants and their features in more detail and will help dispel this terminological confusion.

The research goals of this paper are (i) to verify the existence and distribution of the five alternative constructions for expressing inalienable possession by a first overview of their actual usage in various linguistic contexts, (ii) to explore their differences in meaning and function with respect to text type/register and further pragmatic features derived from typologically relevant characteristics, and (iii) to clarify the case variation between dative and accusative, which is relevant for four out of the five constructions. Our intuition concerning the case alternation (in contrast to Draye's 1996 and Lamiroy and Delbecque's 1998) is that, while accusative-marking of the possessor is preferred for neutrally describing the scene (who did what), dative-marking of the possessor is preferred for drawing attention to the situation of the possessor, i.e. for putting oneself in his/her position.

The remainder of the paper is structured as follows: Section 2 brings in typological findings by Lehmann et al. (2004) concerning general tendencies of encoding possessors. Section 3 establishes what the actual empirical situation is regarding the variation in (2)-(4) with the help of internet and corpus searches and discusses the data in light of our research goals. Section 4 concludes the paper. 
In order to capture the peculiarities of the possessor dative in German, it is useful to broaden the view and take into account some fundamental considerations offered by typological research on argument structure in general, and the possessor dative in German in particular. We take up suggestions by Lehmann et al. (2004), who, building on earlier models (Comrie 1991, Croft 1991, Foley and Van Valin 1984, Langacker 1991, and also Dowty 1991), argue for three macro roles for participant relations: ACTOR, UNDERGOER, and INDIRECTUS, distinguished by the relational features control and affectedness. Most relevant for us is the INDIRECTUS, which has neither maximum control nor maximum affectedness but is maximally empathetic and embodies “co-involvement" ('Mitbetroffenheit,' Lehmann et al. 2004:18), a term, which might help in disentangling the problems associated with the term "affectedness". Macro roles can each be broken down into several micro roles (= thematic roles). The micro role associated with ACTOR that has the most control is AGENT, and the micro role associated with UNDERGOER that has the most affectedness is PATIENT. Most typical of INDIRECTUS, falling in the middle of the scale of micro roles, is the role of RECIPIENT. The role of sYMPATHETICUS, which is crucial for inalienable possession, falls into the range of micro roles associated with both INDIRECTUS and UNDERGOER. Lehmann et al. (2004:19) suggest the following linear ordering of the typologically most important micro roles: AGENT - FORCE - COMITATIVE -INSTRUMENT EXPERIENCER - EMITTENT - RECIPIENT - BENEFICIARY - SYNPATHETICUS - SOURCE - LOCATION GOAL - THEME - PATIENT. The three locative roles (SOURCE, LOCATION and GOAL) are omitted in the following as they are not needed for our argumentation.

The large area of overlap between the ranges of micro roles covered by each macro role is evident from the scales of possible micro roles in Table 2. The prototypical micro roles for each macro role are underlined. As the macro role of INDIRECTUS covers the intermediate space on the scale between ACTOR to UNDERGOER, its prototypical realization as RECIPIENT allows for less prototypical extensions toward both ends of the scale (toward the ACTOR pole via EMITTENT, and towards the UNDERGOER pole via BENEFICIARY).

Table 2: Overview of macro and micro roles (Lehmann et al. 2004:19)

\begin{tabular}{|c|c|}
\hline Macro roles & Micro roles \\
\hline ACTOR & $\begin{array}{c}\underline{\text { AGENT }}<\text { FORCE }<\text { COMITATIVE }<\text { INSTRUMENT }< \\
\text { EXPERIENCER }<\text { EMITTENT }<\text { RECIPIENT }<\text { BENEFICIARY }\end{array}$ \\
\hline UNDERGOER & $\begin{array}{c}\text { PATIENT }<\text { THEME }<\text { SYMPATHETICUS }<\text { BENEFICIARY }< \\
\text { RECIPIENT }<\text { EMITTENT }<\text { EXPERIENCER }\end{array}$ \\
\hline INDIRECTUS & EXPERIENCER $<$ EMITTENT $<\underline{\text { RECIPIENT }>\text { BENEFICIARY }>\text { SYMPATHETICUS }}$ \\
\hline
\end{tabular}


In languages distinguishing three macro roles and using case-marking, the correlation between participant role and case marking results in the typical ditransitive pattern: ACTOR is correlated with nominative, UNDERGOER with accusative, and INDIRECTUS with dative.

The roles described so far express participant relations, i.e. relations defined by the situational core (encoded in the predicate). However, according to Lehmann et al. (2004), there are also interparticipant relations, i.e., relations between individual participants that are independent of the primary situational core. Thus, any participant may simultaneously carry several roles, deriving either from the situational core (participation relation) or from an independent connection among entities functioning as participants (interparticipant relation). The most important interparticipant relation for our purposes here is possession. In a sentence like Erna wäscht Erwin die Haare 'Erna is washing Erwin's hair' (Lehmann et. al 2004:52/21), there is an inalienable possession relation between Erwin as the possessor and die Haare as the possessum. This relation exists independently of the situation expressed by the predicate, namely the situational core (waschen), which consists of the participant relations AGENT (Erna), PATIENT (die Haare), and BENEFICIARY/SYMPATHETICUS (Erwin).

In German, the INDIRECTUS, which is - as expected - marked by the dative, has an exceptionally broad domain of associated micro roles. This is particularly true of possessive relations, where German prefers dative constructions to an extent that is typologically rare. More specifically, while German prefers external ("adverbal") possession, as shown in (7), with the possessor dative as a direct participant in the situational core, inalienable possession in the majority of languages is expressed via internal ("adnominal") possession. Adnominal possession is also a possibility in German, as we saw in (3) of the introduction and as shown here in (8).
a. Ich wasche mir die Hände. I wash me.DAT the hands 'I wash my hands.'

b. Er trägt mir / (der) Susanne die Schleppe. he carries me.DAT / (the.DAT) Susanne the train 'He carries my/Susanne's train (the train of her dress).'
a. Ich wasche meine Hände.
I wash my hands
'I wash my hands.'
b. Er trägt meine/ Susannes Schleppe. he carries my / Susanne's train 'He carries my/Susanne's train (the train of her dress).'

To reiterate, the prototypical German strategy for expressing inalienable possession is the realization of an adverbal possessor, which makes the possessor a direct participant of the 
situation (as BENEFICIARY/SYMPATHETICUS). ${ }^{4}$ It backgrounds the possession relation, which is merely the result of pragmatic inferencing, though it is the stereotypical inference. That is, in (7b), mir...die Schleppe, the possession relation between me as the possessor and the train as the possessum, which is the standard interpretation, is not explicitly expressed but inferred. On the other hand, the typologically unmarked strategy qua adnominal possessor in (8b), er trägt meine Schleppe, is dispreferred in German. It backgrounds the participation of the possessor as playing an independent role in the verbal scene, putting emphasis on the possession relation, which is explicitly encoded.

In addition to these two options, there is a third strategy, as we saw in (4) of the introduction and as illustrated in (9) here, which combines the first two strategies and therefore leads to a "double encoding" of the possessor via the optional addition of a possessive pronoun to an already externally expressed possession relation. This option is cross-linguistically marginal and also the least commonly used one in German.
a. Ich wasche mir meine Hände. I wash me.DAT my hands 'I wash my hands.'
b. Er trägt mir / (der) Susanne meine/ihre Schleppe. he carries me.DAT / (the.DAT) Susanne my/her train 'He carries my/Susanne's train (the train of her dress).'

The three strategies of expressing possession in German discussed in this section are summarized here in Table 3.

4 Our use of the term "strategy" is inspired by Lehmann et al. (2004:27) who define "strategy" as "the sum of cooccurring operations for the generation of a type of syntactic construction'. The full German quote is: "Das strukturelle Gegenstück einer Perspektive auf eine Situation ist eine Strategie zu ihrer sprachlichen Repräsentation, also eine Menge kookkurrenter Operationen zur Erzeugung eines Typs von syntaktischer Konstruktion". Lehmann et al. distinguish, for example, strategies that emphasize interparticipant relations and at the same time de-emphasize participant relations (e.g. the genitive possessor in Sie bügelt Peters Hemden 'She irons Peter's shirts'), from others having the opposite effect (e.g. the external possessor construction). They use the term "strategy" for cross-linguistic and typological comparison; we apply it here to the encoding options of the German language. 
Table 3: Strategies for expressing possession relations in German

\begin{tabular}{|c|c|c|c|}
\hline & Strategy 1 & Strategy 2 & Strategy 3 \\
\hline & $\begin{array}{l}\text { Adverbal realization of } \\
\text { the possessor (see }(7))\end{array}$ & $\begin{array}{l}\text { Adnominal realization of } \\
\text { the possessor }(\text { see }(8))\end{array}$ & $\begin{array}{l}\text { Double encoding of } \\
\text { possessor }(\text { see }(9))\end{array}$ \\
\hline Features & $\begin{array}{l}\text { - Direct participation of } \\
\text { the possessor in the } \\
\text { situation } \\
\text { - Participant relation is } \\
\text { foregrounded } \\
\text { - Possession relation is } \\
\text { inferred via pragmatic } \\
\text { inferencing }\end{array}$ & $\begin{array}{l}\text { - Indirect participation of } \\
\text { the possessor in the } \\
\text { situation } \\
\text { - Participant relation is } \\
\text { backgrounded } \\
\text { - Possession relation is } \\
\text { explicitly encoded }\end{array}$ & $\begin{array}{l}\text { - Possessive relation is } \\
\text { represented twice } \\
\text { (externally and internally) } \\
\text { - Explicit expression of } \\
\text { direct participant relation } \\
\text { - Explicit expression of } \\
\text { possession relation }\end{array}$ \\
\hline Status & Prototypical & Dispreferred & Marginal \\
\hline Effect & $\begin{array}{l}\text { Participation wins over } \\
\text { possession }\end{array}$ & $\begin{array}{l}\text { Possession wins over } \\
\text { participation }\end{array}$ & $\begin{array}{l}\text { Participation and } \\
\text { possession are equally } \\
\text { prominent }\end{array}$ \\
\hline
\end{tabular}

The dative/accusative variation in the external possessor, which we saw in (2a-b) and (4ab) of the introduction, can be seen as a fourth strategy, which is, however, severely restricted by lexical and other factors. To explain the motivation for this variation, we appeal to Lehmann et al.'s (2004:57) discussion of different degrees of analogous affectedness. In situations with analogous affectedness (Erna schlug Erwin (ACC/DAT) auf den Kopf 'Erna hit Erwin on the head' $>$ Erna schlug Erwin 'Erna hit Erwin'), the possessor plays the role of a SYMPATHETICUS and, via implication, acquires the role of a PATIENT as well. In situations with non-analogous affectedness (Erna brach Erwin (DAT) den Arm 'Erna broke Erwin the arm' // Erna brach Erwin 'Erna broke Erwin'), the possessor is only a SYMPATHETICUS, not also a PATIENT.

Extending Lehmann et al.'s discussion, we argue that the use of an accusative-marked possessor in the external possessor construction expresses possessor and possessum (the PATIENT) as analogously affected, i.e. the possessor is also seen as PATIENT (this goes with meaning (a) of "affectedness" in section 1). The use of a dative-marked possessor, on the other hand, draws attention to the possessor as a SYMPATHETICUS, a direct participant of the situation whose involvement is independent of the PATIENT (this goes with meaning (b) of "affectedness" in section 1, where we have co-involvement/co-participation of an animate entity). Thus, dativemarking should express more empathy for the possessor than accusative-marking. This predicts that the dative/accusative variation found in our data is indeed not random or arbitrary but a consequence of stylistic or expressive choice - given that the syntactic conditions concerning accessible valency frames are met. ${ }^{5}$ As stated in the introduction, our intuition is that a dative-

5 As pointed out in section 1, the variation is constrained by the verb's subcategorization (semantic and syntactic selectional) requirements. Only verbs that inherently express directed motion and can be used either transitively (with a directional PP adjunct) or intransitively (with a directional PP argument) participate in the 
marked possessor is used for drawing attention to the situation of the possessor, while an accusative-marked possessor is used for neutrally describing the situation (who did what).

To wrap up this section, German allows for the possibility of the possessor participant to be furnished with one or more of the micro roles associated with the INDIRECTUS. As the INDIRECTUS has a broad range of associated micro roles, the potential for various more specific interpretations of the micro role(s) is particularly large, depending on the situation type. For the expression of possession relations, strategy 1 together with a dative-marked external possessor is the unmarked case (= example (2a)), with the others being used, whenever a particular type of foregrounding and backgrounding between possession relation and participant relation is preferred.

Based on the reflections presented so far, we can now add some specifications to our goals stated at the end of section 1. As a specification of goals (ii) and (iii), we assume that for a comprehensive description of inalienable possession constructions in German, the following three pragmatic features, which can be seen as a condensed notation of the strategies described above, are useful: defocusing, expressiveness and objectivity. By defocusing, we refer to the reduction of the participant status of the possessor, i.e. the constructions in (2a-b) receive the feature value [-defocusing], while the internal possession construction receives the feature value [+defocusing]. By expressiveness, on the other hand, we refer to the process of exceeding the default value by being more explicit and using more linguistic material than necessary. As the default method for expressing inalienable possession in German is the external possessor construction (both variants $(2 \mathrm{a})$ and $(2 \mathrm{~b})$ ), it receives the feature value [-expressive], while the doubly-marked constructions in (3a-b) receive the feature value [+expressive]. Finally, objectivity is used here to label the effect of the case variation in the external possessor: the dative-marked external possessor receives the feature value [-objectification], while the accusative-marked external possessor receives the feature value [+objectification]. We assume that the feature grid of each single usage of an inalienable possession construction is interpreted for a variety of textual and pragmatic functions. The next section presents a first test for our model on the basis of an empirical investigation.

\section{The Empirical Situation}

Section 3.1 reports on the results of a pilot search we conducted via Google; section 3.2 describes the methodology and results of two extensive corpus searches, one of a written and the other of a spoken corpus of modern German, as well as further extensive search via Google; and section 3.3 interprets the results.

\subsection{Pilot Search}

We used Google for a first exploratory random search, entering search strings like in [...] Nase beißen/gebissen/biss 'in [...] nose bite/bitten/bit' (e.g. in die/seine/ihre Nase gebissen 'in

dative/accusative alternation. 
the/his/her nose bitten') and categorized our findings as shown in Table 4. We include one or two hits per example type.

Table 4: Sample hits of pilot search

\begin{tabular}{|c|c|}
\hline Example Type & Sample Hits \\
\hline $\begin{array}{l}\text { A. } \\
\text { ACC-external } \\
\text { possessor and } \\
\text { DAT-external } \\
\text { possessor in } \\
\text { the same text }\end{array}$ & $\begin{array}{l}\text { (i) } \\
\text { Hallo, bin neu hier und muss gleich mein Problem los werden...mein kleiner } \\
\text { Pascha (3 Monate alter Jack-Russell-Terrier) hat mich gestern in die Nase } \\
\text { gebissen. Zuerst haben wir wie immer total lieb miteinander gespielt, [...]. } \\
\text { Dabei hab ich mich etwas zu ihm herab gebeugt und Pascha sprang hoch und } \\
\text { biss mir in die Nase. Ich musste sogar zum Arzt, da es so stark geblutet hat. } \\
\text { 'Hello, am new here and have to share my problem right away...my little } \\
\text { Pascha (3-month-old Jack Russell Terrier) bit me (ACC) in the nose yesterday. } \\
\text { First we played nicely as always, [...]. At that point I bent down to him a little } \\
\text { bit and Pascha jumped up and bit me (DAT) in the nose. I even had to go to the } \\
\text { doctor because there was so much bleeding.' } \\
\text { (http://www.dogforum.de/hilfe-mein-hund-hat-mich-in-die-nase-gebissen- } \\
\text { t57915.html; } 21.08 .2008 \text { 20:25) }\end{array}$ \\
\hline $\begin{array}{l}\text { B. } \\
\text { External/ } \\
\text { internal } \\
\text { possessor } \\
\text { variation } \\
\text { between texts } \\
\text { and in the } \\
\text { same text }\end{array}$ & $\begin{array}{l}\text { (i) } \\
\text { ist ihnen auch schon aufgefallen, oder wussten sie schon, dass } 10 \text { monate alte } \\
\text { sänglinge mit nur vier zähnen trotzdem richtig fest in ihre nase beißen } \\
\text { können? } \\
\text { 'have you noticed, or do you happen to know already, that 10-month-old } \\
\text { infants with only four teeth can nonetheless bite into your nose really hard?' } \\
\text { (http://lamamma.twoday.net/stories/11497757/comment 19.12.2010 19:17) } \\
\text { (ii) } \\
\text { Der Freundin aus Wut in die Nase gebissen } \\
\text { Amtsgericht Jena [...] } \\
\text { Petra habe sich an seiner Jacke festgekrallt und sei ihm dabei ganz nahe } \\
\text { gekommen. Da habe er reflexartig in ihre Nase gebissen. Das alles tue ihm } \\
\text { nun wahnsinnig leid. [...] } \\
\text { 'Girlfriend bitten into the nose out of anger } \\
\text { Courthouse Jena [...] } \\
\text { Petra allegedly clawed herself into his jacket and got very close to him. Then, } \\
\text { as if triggered by a reflex, he bit into her nose. He now deeply regrets every- }\end{array}$ \\
\hline
\end{tabular}




\begin{tabular}{|c|c|}
\hline & $\begin{array}{l}\text { thing that happened. [...]' } \\
\text { (http://stadtroda.otz.de/web/lokal/leben/detail/-/specific/Der-Freund- } \\
\text { in-aus-Wut-in-die-Nase-gebissen-1196906345; 01.08.2012 09:30 }\end{array}$ \\
\hline $\begin{array}{l}\text { C. } \\
\text { "Doubly- } \\
\text { marked" } \\
\text { possessors: } \\
\text { Combined } \\
\text { external and } \\
\text { internal } \\
\text { possession }\end{array}$ & 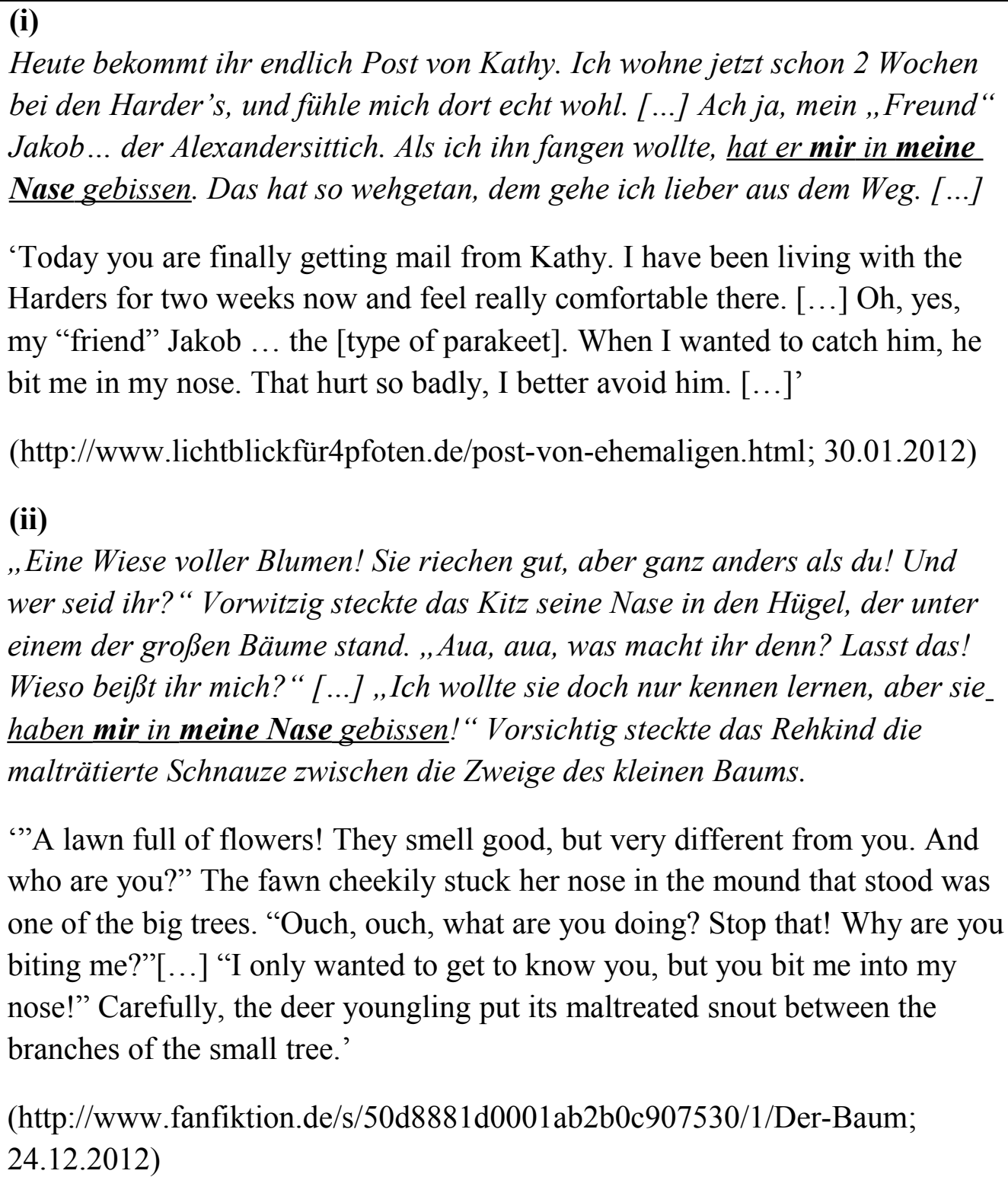 \\
\hline
\end{tabular}

As the hypothesized four strategies based on Lehmann et al. (2004) predict, the empirical situation points to high variability and a very flexible application of the basic morphosyntactic patterns. The default construction with an external dative-marked possessor is represented twice, in the second instance of A (i), and in the first instance of B (ii). These two examples involve the features [-defocusing], [-expressive], [-objectification]. The justification for that becomes very clear when we look at the other marked, non-default constructions, which - as can be seen in A and $\mathrm{B}$ - occur alternatingly with the default construction in one and the same text. We cannot 
present a comprehensive analysis here, but we provide at least some support for our assumption of the semantic-functional differentiation between the constructions.

Example A (i) supports our intuition concerning the dative/accusative alternation that accusative-marking of the possessor is used when the possessor's involvement is neutrally stated, and that dative-marking of the possessor is used when the addressee is supposed to take the possessor's perspective as an empathically involved participant. In the example, the possessor is the speaker/writer, and the text is a personal account. The first two instances of external possession are accusative external possessors ( $m i c h$ ), and they occur in the headline (here seen in the name of the link below the example) and initial statement of the facts, when the audience does not know the speaker/writer yet. The realized features in these constructions are [-defocusing], [-expressive], and [+objectification] and account for the textual effect of these two instances of external possessors (stating the full-blown situation by introducing all participants, avoiding expressiveness, reducing "subjective" co-involvement by choosing the accusative case for the possessor and thus objectivizing this participant, emphasizing its patient features, i.e. its analogous affectedness as the bitten entity in the biting scene). The third instance of an external possessor in A (i) has dative marking (mir), and, at this point, the account is more personal. The audience knows the speaker/writer better and feels for her. Here, the speaker/writer can rely on the default construction with all three features displaying the unmarked value, i.e. [-defocusing], [-expressive], and [-objectification].

In example B (i), where we have an internal possessor, associated with the features [+defocusing], [-expressive], [Ø objectification $]^{6}$, the possessor is the addressee/reader. The speaker/writer makes a generic statement about the nose-biting behavior of 10-month-olds and addresses the reader using the polite form of address (Ihre Nase instead of eure Nase 'your nose'). Here, the distance between the speaker/writer and the audience seems even greater than in the instances of accusative external possession in A (i). The addressee is not emphasized as a co-involved participant in the biting scenario, only as possessor of the nose.

Interestingly, both examples $\mathrm{C}$ (i) and (ii), where we have doubly-marked possession, i.e. the features [-defocusing], [+expressive], [-objectification], are from texts (a letter and a fictional piece of writing, respectively) in which animals speak. The first example is a quote from a dog, and the second is a quote from a baby deer. This is a first indication of the relative marginality of the doubly-marked possession construction, which obviously is associated with communicative situations of a somewhat "overexpressive" kind of emphasis. As our main corpus search results listed in the following subsection show, this construction is indeed rare.

\subsection{More Extensive Corpus Work}

Our pilot search helped us isolate five verbs for our search strings: beißen 'bite', boxen 'box', hauen 'hit', schlagen 'hit', and treten 'kick/step'. Other verbs participating in the dative/ accusative alternation do not occur frequently enough (e.g. kneifen 'pinch' and zwicken 'pinch')

6 As the third feature [+/-objectification] refers to the case alternation in the external possessor, it receives a zero value in the internal possessor construction. 
or have slightly different lexical meanings depending on the case of the possessor (e.g. streicheln 'caress' vs. 'stroke' and ziehen 'pull' vs. 'drag'; see Lee-Schoenfeld 2012). ${ }^{7}$ The body part PPs in our search strings, listed in Table 5, were chosen based on native-speaker intuition and our pilot search, with the goal of using the most frequently occurring combinations of PP + verb. The ellipsis symbol means that either a determiner or a possessive pronoun could be preceding the body part.

Table 5: Search strings ${ }^{8}$

\begin{tabular}{|l|l|}
\hline Verb & Strings entered \\
\hline beißen 'bite' & $\begin{array}{l}\text { in ... Hand gebissen ('in ... hand bitten') } \\
\text { in ... Nase gebissen ('in ... nose bitten') }\end{array}$ \\
\hline boxen 'box/punch' & in ... / ins Gesicht geboxt ('in ... / in-the face boxed/punched') \\
\hline hauen 'hit' & $\begin{array}{l}\text { in ... Fresse gehauen ('in ... mouth hit') } \\
\text { in ... / ins Gesicht gehauen ('in ... / in-the face hit') } \\
\text { auf ... Kopf gehauen ('on ... head hit') } \\
\text { auf ... Po gehauen ('on ... butt hit') }\end{array}$ \\
\hline schlagen 'hit' & $\begin{array}{l}\text { in ... / ins Gesicht geschlagen ('in ... / in-the face hit') } \\
\text { auf ... Hand geschlagen ('on ... hand hit') }\end{array}$ \\
\hline treten 'kick/step' & $\begin{array}{l}\text { in ... Bauch getreten ('in ... belly kicked') } \\
\text { auf ... Fuß getreten ('on ... foot stepped') } \\
\text { in ... Magen getreten ('in ... stomach kicked') } \\
\text { auf ... Zehen getreten ('on ... toes stepped') }\end{array}$ \\
\hline
\end{tabular}

The corpus consulted for our first search, henceforth Corpus Search 1 (C1), was Cosmas II, Institut für Deutsche Sprache (IDS), Mannheim (https://cosmas2.ids-mannheim.de/somas2web/menu.home.do), which consists of written modern German taken from a wide variety of German newspapers, the total number of word forms being 8,9 billion, approximately 22,2 million book pages.

The corpus consulted for our second search, henceforth Corpus Search 2 (C2), was Datenbank für Gesprochenes Deutsch (DGD) 2, Institut für Deutsche Sprache (IDS), Mannheim (https://dgd.ids-mannheim.de:8080/dgd/pragdb.dgd_extern.welcome), which is in the process of being built up and consists of spoken modern German of different genres and regional varieties,

7 The meaning of streicheln used with a directional PP-argument and dative-marked possessor is 'stroke (as a directed motion, from point A to point B)' as in Sie streichelte mir mit der Hand über den Kopf (lit. 'She stroked me with the hand across the head'), while the meaning of the same verb with a PP-adjunct and an accusativemarked possessor is 'caress (without directed motion)', as in Sie streichelte mich am Kopf 'She caressed me on the head'. The meaning of ziehen used with a dative-marked possessor is 'pull', as in Er zog mir an den Haaren 'He pulled on my hair', but when used with an accusative-marked possessor, the meaning is more likely to be 'drag', as in Er zog mich an den Haaren durch das Zimmer 'He pulled me by the hair across the room'.

8 We only entered the participle form of each verb for our written corpus search ( $\mathrm{C} 1$, see below), while we worked with all verb forms (e.g. beiß-, biss-, gebissen 'bite, bit, bitten') for the spoken one (C2, see below). In our spoken corpus search, we also allowed for free variation concerning body part and directional preposition. The reason is that, as mentioned as part of the interpretation of our search results, the written corpus we worked with is much larger than the spoken one. 
the current total number of word forms being 7,367,432 (as of January 2014). As will be discussed later, the fact that the IDS spoken corpus, DGD2, is significantly smaller than the IDS written corpus, Cosmas II, is reflected in the relatively small number of hits in $\mathrm{C} 2$.

No hits were found for internal possessors (see (3): ... hat in meine Hand gebissen 'bit in my hand') or doubly-marked possessors (see (4): ... hat mir/mich in meine Hand gebissen 'bit me.DAT/ACC in my hand'). The number of tokens for external possessors (see (1a-b) ... hat mir/mich in die Hand gebissen 'bit me.DAT/ACC in the hand') are given in Tables 6 and 7.

Table 6: Results of C1 and C2 (external possession construction)

\begin{tabular}{|c|c|c|c|c|}
\hline & Total \# of Ext. Poss. & ACC & DAT & Unclear \\
\hline $\begin{array}{c}\text { C1 } \\
\text { (written) }\end{array}$ & 100 & 32 & 67 & $\begin{array}{c}1 \text { item either ACC } \\
\text { or DAT }\end{array}$ \\
\hline $\begin{array}{c}\text { C2 } \\
\text { (spoken) }\end{array}$ & 16 & 6 & 8 & $\begin{array}{c}2 \text { items either } \\
\text { ACC or DAT }\end{array}$ \\
\hline Total & 116 & $\mathbf{3 8}$ & $\mathbf{7 5}$ & 3 \\
\hline
\end{tabular}

Table 7: Case variation per verb

\begin{tabular}{|l||c|c||c|c|}
\hline Verb & C1: ACC & C1: DAT & C2: ACC & C2: DAT \\
\hline beißen 'bite' & 11 & 15 & 2 & 3 \\
\hline boxen 'box' & 5 & 9 & 0 & 0 \\
\hline hauen 'hit' & 1 & 13 & 0 & 0 \\
\hline schlagen 'hit' & 5 & 10 & 3 & 2 \\
\hline treten 'kick/step' & 10 & 20 & 1 & 3 \\
\hline
\end{tabular}

Due to the unexpectedly small number of hits in $\mathrm{C} 2$ and the fact that we had no hits for internal and doubly-marked possessors in either $\mathrm{C} 2$ or $\mathrm{C} 1$, we conducted a third search via Google (C3), entering the search strings given in Table 5 with the exception of the string listed for the verb boxen 'box/punch'. The results of this search are given in Table 8. 
Table 8: Results of C3 (internal and doubly-marked possession constructions) $)^{9,10}$

\begin{tabular}{|l|c|c|c|c|c|c|}
\hline Verb & Int. Poss. & $\begin{array}{c}\text { Double } \\
\text { Poss. } \\
\text { Total }\end{array}$ & $\begin{array}{c}\text { Double } \\
\text { Poss. } \\
\text { ACC }\end{array}$ & $\begin{array}{c}\text { Double } \\
\text { Poss. } \\
\text { DAT }\end{array}$ & $\begin{array}{c}\text { Double } \\
\text { Poss. } \\
\text { Unclear }\end{array}$ & (Ext. Poss.) \\
\hline $\begin{array}{l}\text { beißen } \\
\text { 'bite' }\end{array}$ & 154 & 40 & 19 & 16 & 5 & $(546)$ \\
\hline $\begin{array}{l}\text { hauen } \\
\text { 'hit' }\end{array}$ & 122 & 77 & 11 & 57 & 9 & $(1041)$ \\
\hline $\begin{array}{l}\text { schlagen } \\
\text { 'hit' }\end{array}$ & 129 & 45 & 18 & 22 & 5 & $(409)$ \\
\hline $\begin{array}{l}\text { treten } \\
\text { 'kick/step' }\end{array}$ & 214 & 70 & 8 & 52 & 10 & $(884)$ \\
\hline Total & 619 & 232 & $\mathbf{5 6}$ & $\mathbf{1 4 7}$ & 29 & $(2880)$ \\
\hline
\end{tabular}

\subsection{Interpretation of Search Results}

Although a comparison between our written and spoken corpus search results is difficult due to the surprisingly small number of hits our spoken corpus search yielded, and although neither the written nor the spoken corpus had any tokens of internal or doubly-marked possession, our corpus work as a whole does allow us to draw some valuable conclusions.

First, all three searches $(\mathrm{C} 1, \mathrm{C} 2$, and $\mathrm{C} 3)$ confirm that dative-marked external possessors are indeed the most common choice in German inalienable possession constructions. The number of external possessor tokens (2880) is much higher than the number of internal possessor tokens (619) in C3, and within both external possession and doubly-marked possession, there are more dative-marked than accusative-marked possessors. In $\mathrm{C} 1$ and $\mathrm{C} 2$, of the total number of external possessors, 75 are dative-marked and only 38 are accusative-marked. Similarly, in C3, of the total number of doubly-marked possessors, 147 bear dative case and only 56 accusative case. This confirms the assumptions that dative marking, not accusative marking, of the external possessor is the default (see e.g. Wegener 1985). In our description this is accounted for by attributing the marked feature of [+objectification] to the accusative external possessor.

Second, the case variation between dative and accusative in the external possessor occurred in all three corpora, and - as far as a first interpretation can tell - it varies in a uniform way. In order to get at the motivation for the observed alternation, and to test our descriptive feature of objectification here, we ran a test including all tokens of $\mathrm{C} 1$ (which is the most

9 Token numbers for external possession are listed in the rightmost column for comparison.

10 Some remarks on the general layout of the research in C3: We did not run statistical tests because (i) the constructions under investigation occurred too infrequently in the corpora we worked with and (ii) Google, while great for a pilot search, is simply not well-suited for a systematic, quantitatively analyzed corpus search for linguistic purposes. Some hits are on pages that are no longer accessible, others cannot be copied from the page they are found on, and again others are too extreme in content to include, etc. We therefore stick to an analysis that is more qualitative than quantitative. 
homogeneous one of our corpora as it consists of written language only) and made the following distinction between formal and informal register. We considered the register to be formal when the source was a court or police report, written to be maximally neutral/unbiased. We also took use of subjunctive indicating reported speech and adverbials like allegedly (or other evidentiality markers) to be signs of formal register. On the other hand, we considered the register to be informal when the source was a narration written in the $1^{\text {st }}$ person or a quotation providing a $1^{\text {st }}$ person account of whatever event was being reported on. Given these definitions of formal and informal, we found what is summarized in Table 9.

Table 9: Use of dative vs. accusative-marked external possessors in formal vs. informal registers

\begin{tabular}{|l|c|c|c|}
\hline & Total Ext. Possessors & DAT & ACC \\
\hline Formal Register & 78 & 48 & 29 \\
\hline Informal Register & 22 & 19 & 3 \\
\hline
\end{tabular}

We were able to confirm the validity of our description of the respective constructions. Of the 100 total tokens for external possession constructions, a clear majority, 78\%, appeared in the formal register and only $22 \%$ in the informal register, as expected given a written corpus consisting of news articles. Importantly, of the 32 tokens for accusative-marked possessors, almost all, $90.6 \%$, were found in the formal register and only $9.4 \%$ in the informal register. In contrast, of the 67 tokens for dative-marked possessors, only $71.6 \%$ were in the formal register and thus a good amount, $28.4 \%$, in the informal register. This means that, in the few instances of informal register, dative-marked possessors were clearly preferred, namely in 19 of 22 hits, that is, $86.3 \%$ of the time. This in turn means that, when there was a deviation from the prototypical strategy of encoding external possessors, i.e. when accusative was used instead of dative, namely $32.3 \%$ of the time, then it happened almost exclusively in the formal register.

Since the informal register correlates with subjectively told events characterized by the narrator or speaker wanting to convince the reader or listener by getting them to empathize, while the formal register correlates with writings that are meant to be completely neutral descriptions of the facts, we take our $\mathrm{C} 1$ findings in Table 9 to confirm the intuition that dative is used to draw attention to the situation of the possessor, whereas accusative is used when a neutral scene description is called for. In terms of Lehmann et al. (2004), a dative possessor is a non-core participant, a SYMPATHETICUS, whose involvement is emphasized because it is not dependent on the affected body part, the PATIENT, while an accusative possessor's involvement does depend on the PATIENT because possessor and PATIENT are analogously affected. In short, our corpus search results are in line with Lehmann et al., suggesting that the choice between dative and accusative marking of the external possessor depends on the participant status of the possessor. The more involved in the core situation the possessor is, independently of the affected body part (from the perspective of the speaker), the more likely it will be expressed as a dativemarked nominal, emphasized in its role of sYMPATHETICUS. The more the possessor is identified 
with the affected body part, the more likely it will be expressed as an accusative-marked nominal, playing the role of a (not necessarily empathy-invoking) PATIENT.

We are confident that these results can be generalized to other corpora, for example, corpora containing spoken language or language used in internet exchanges like our C2 and C3 corpora. The data in the appendix point in this direction. The external possessor construction with a dative-marked possessor is illustrated in appendix examples (A1-9), and the one with an accusative-marked possessor in appendix examples (A10-18). The latter ones show that the feature of [+objectification] is made use of to add neutrality (as compared to the default construction with a dative-marked possessor) in different communicative situations, i.e. with different pragmatic effects. For instance, accusative-marked possessors are found in reports on events in which the speaker/writer does not directly participate but acts as a witness (see (A10), (A13), (A16), and (A18)). Another typical constellation is found in more personal accounts where the speaker/writer is directly involved, but where they want to downplay the effect of the action on them (e.g. because a child or a pet did something unwelcome without bad intentions (see (A11), (A12), and (A14)). The same situation - mutatis mutandis - is found in the doublymarked constructions (see the contrast between (A22-24) with dative possessors and (A25-27) with accusative possessors). However, these first results have to be confirmed by an extended study.

Third, the general prevalence of the dative case in the external possession construction, regardless of formality of register, can probably be explained by appealing to several factors coming into play in different ways. One factor is that the construction is well-established as the default construction in many European languages (see section 2 of Haspelmath 2001). Furthermore, as we discussed in section 2, the dative, representing the macro role of INDIRECTUS in German can encode a particularly broad domain of micro roles, which is reflected in the large variety of dative constructions, including "free datives", i.e. datives not assigned to a core argument of the verb, in modern German (Zifonun et al. 1997). The participant roles of these datives span from EXPERIENCER to SYMPATHETICUS and often overlap (Wegener 1985). Whether inalienably possessed or not, and whether there is a possessum embedded in a PP or not, the "affectee" or "co-involved" animate participant in the situation described by the verb is dative-marked in German (for the exact syntactic and semantic conditions, see e.g. Primus 2012). ${ }^{11}$

Fourth, as for the frequency of the two marked (non-standard) constructions, internal and doubly-marked inalienable possession constructions, C3 confirms that, while these construction types are marked compared to external possession, they are in fact being used and are not rare in informal contexts like blogs. Their lack of occurrence in C2, our spoken corpus search, where we expected non-standard construction types to show up relatively frequently, can again be attributed to the small size of the corpus. Thus, overall, our study confirms that internal and doubly-marked inalienable possession constructions do need to be accounted for, and we have shown that Lehmann et al. (2004) provide the right kind of framework for such an account. The

11 "Affectee" is again used here in the sense of 'entity taking part in the situation as an empathetic, necessarily animate co-participant', as explained in section 1. 
prediction that German makes available four different strategies (yielding five constructions) for encoding possessors, depending on the degree to which possession and participation are intended to be foregrounded or backgrounded, is borne out.

Fifth, as illustrated by the sample tokens for C3 given in the appendix (see (A19-21)), the internal possession strategy really does seem to be used in order to downplay the participation of the possessor and is thus a purposeful deviation from the default variant. It creates distance between narration and audience. No empathy with the possessor is intended, which is represented in our model by the feature [+defocusing]. Instead, if anything, extra attention is drawn to the agent (see (A20-21)). Another possible reason for the use of internal possession is that the involvement of the possessor was just mentioned, often via use of a dative pronoun in the immediately preceding clause or sentence (see (A19)).

Sixth, the function of the doubly-marked possession is the most restricted one, which correlates with its rare usage. As indicated by the feature [+expressive], it is used for exaggerated emphasis of everyone's involvement in the situation, often in the context of children being addressed or the fictional situation of an animal speaking his or her mind (see the discussion of the data from our pilot study in section 3.1). As the material in the appendix shows, the doublymarked possession construction, or more specifically, the feature [+expressive], can be put to further pragmatic usages. It can be used to highlight the climax in personal narratives of dramatic events (see (A23-24)), or it can be used in neutral reports on events that need to be maximally clear as to who did what and whose body part was involved (see (A25-27)). Unsurprisingly, it is the construction with an accusative-marked possessor (with the features [-defocusing], [+expressive], [+objectification]) that is particularly prone to be used for this purpose.

Summing up the less fine-grained variation between external (adverbal), internal (adnominal), and doubly-marked possession, it simply comes down to whether the speaker wants to emphasize the possessor's core participant role of SYMPATHETICUS, his/her non-core interparticipant role of POSSESSOR, or both. Internal possession with a body-part possessum seems to be a coercion of inalienable possession into an alienable possession construction, which has the purpose of maximally downplaying the significance of the possessor's role in the core situation expressed by the verb.

\section{Conclusion}

Supported by the results of extensive corpus work consisting of three separate searches, we have shown that the variation found in German inalienable possession constructions with a PPembedded body part is not random but rather serves pragmatic purposes. We were able to distinguish and confirm the existence of five constructions for inalienable possession in German.

By combining the typologically informed conception of participation and participant roles of Lehmann et al. (2004) and the attribution of feature values (of the features defocusing, expressiveness, and objectification) to each of the five constructions, we proposed semantic and functional distinctions between the constructions that we proved to be valid in a test with corpus data. 
Not wanting to repeat the results of the data analysis given in 3.3, we conclude by pointing to issues that need further study: the marked constructions need to be studied more thoroughly; the exact conditions and motives for variation between all constructions await further research, also taking into account factors like textual progression; the exact range of verbs participating in the dative/accusative alternation for the external possessor needs to be asserted; the influence of the category of person and the exact semantic and morphosyntactic structure of the possessor (first person versus non-first person, pronoun versus full NP or proper name, etc.) on the function of the construction has to be looked into; and a controlled larger corpus of suitable informal language data has to be used to deepen the results.

In our view, these are important desiderata for a better understanding of inalienable possession constructions in German, and a further study tackling these issues is underway.

\section{$5 \quad$ References}

Comrie, Bernard 1989. Language Universals and Linguistic Typology. Syntax and Morphology ( $2^{\text {nd }}$ edition). Oxford: Blackwell.

Croft, William 1991. Syntactic Categories and Grammatical Relations. The Cognitive Organization of Information. Chicago/London: The University of Chicago Press.

Deal, Amy Rose. To appear. External possession and possessor raising. In Martin Everaert and Henk van Riemsdijk, eds., The Companion to Syntax ( $2^{\text {nd }}$ edition). Hoboken: WileyBlackwell.

Dowty, David. 1991. Thematic Proto-Roles and Argument Selection. Language 67: 547-619.

Draye, Luk. 1996. The German Dative. In van Belle, William, and Willy van Langendonck, eds., The Dative. Volume 1: Descriptive Studies, pp. 155-215. Amsterdam: John Benjamins.

Foley, William, and Robert Van Valin. 1984. Functional Syntax and Universal Grammar. Cambridge: Cambridge University Press.

Haspelmath, Martin. 2001. The European linguistic area: Standard Average European. In Haspelmath, Martin et al., eds., Language Typology and Language Universals, 2nd half of volume, pp 1492-1510. Berlin: Mouton de Gruyter.

Hole, Daniel. 2005. Reconciling "Possessor Datives" and "Beneficiary Datives" - Toward a Unified Account of Dative Binding in German. In Maienborn, Claudia, and Angelika Wöllstein, eds., Event Arguments: Foundations and Applications, pp. 213-242. Tübingen: Narr.

König, Ekkehard and Volker Gast. 2012. Understanding English-German Contrasts (3 ${ }^{\text {rd }}$ revised edition). Berlin: Erich Schmidt Verlag.

Lamiroy, Béatrice, and Nicole Delbecque. 1998. The Possessive Dative in Romance and Germanic Languages. In van Belle, William and Willy van Langendonck, eds., The Dative. Volume 2: Theoretical and Contrastive Studies, pp. 29-74. Amsterdam: John Benjamins. Langacker, Ronald. 1991. Foundations of Cognitive Grammar II: Descriptive Application. Stanford, CA: Stanford University Press. 
Lee-Schoenfeld, Vera. 2006. German Possessor Datives: Raised and Affected. Journal of Comparative Germanic Linguistics 9: 101-142.

Lee-Schoenfeld, Vera. 2007. Beyond Coherence: The Syntax of Opacity in German. Amsterdam: John Benjamins.

Lee-Schoenfeld, Vera. 2012. Case and Affectedness in German Inalienable Possession Constructions. Linguistische Berichte 232: 399-416.

Lee-Schoenfeld, Vera and Gabriele Diewald. 2013. Explaining case variation in German inalienable possession constructions. In Stefan Huber, ed., Tampa Papers in Linguistics 4:3143.

Lehmann, Christian, Yong-Min Shin, and Elisabeth Verhoeven. 2004. Direkte und indirekte Partizipation. Zur Typologie der sprachlichen Repräsentation konzeptueller Relationen ( $2^{\text {nd }}$ edition). Arbeitspapiere des Seminars für Sprachwissenschaft der Universität Erfurt 13.

McIntyre, Andrew. 2006. The Interpretation of German Datives and English have. In Abraham, Werner, Daniel Hole, and André Meinunger, eds., Datives and Other Cases, 185-211. Amsterdam: John Benjamins.

Payne, Doris and Immanuel Barshi. 1999. External Possession. Amsterdam: John Benjamins. Primus, Beatrice. 2012. Semantische Rollen. Heidelberg: Universitätsverlag Winter. Pylkkänen, Liina. 2008. Introducing Arguments. Cambridge, MA: MIT Press. Wegener, Haide. 1985. Der Dativ im heutigen Deutsch. Tübingen: Narr. Zifonun, Gisela, Ludger Hoffmann, Bruno Strecker [et al.].1997. Grammatik der deutschen Sprache. Berlin: Mouton de Gruyter. 


\section{Appendix: Sample tokens from the three corpora C1, C2, and C3}

The examples are ordered according to the five different constructions: (i) EPC_DAT, (ii) EPC_ACC, (iii) IPC, (iv) DMPC_DAT, (v) DMPC_ACC. For each construction there are examples with the verbs beißen 'bite', schlagen 'hit' and treten 'kick, step'. The default constructions EPC_DAT and EPC_ACC are found in all three corpora C1, C2, and $\mathrm{C} 3$, and we give examples from all of them in order to demonstrate the homogeneity of the usage of the external possessor constructions in German. The marked constructions IPC, DMPC_DAT and DMPC_ACC were only found in C3. We give typical examples illustrating the particular textual functions of each marked construction as referred to in the text section.

\section{(i) External possession construction with dative possessor: EPC_DAT}

Beißen 'bite'

(A1) Er sei völlig perplex über die Aggression des jungen Mannes gewesen, "dass er dem Badegast nicht in die Nase gebissen hat, war alles", that he the.DAT bath-guest not in the nose bitten has was all wunderte er sich. Als er ihm einen Platzverweis ausgesprochen habe, sei eine richtige Hasstirade auf ihn losgegangen.

C1 (RHZ04 Rhein-Zeitung 2004)

"He claimed to have been totally perplexed about the aggression of the young man, "it was a wonder that he did not bit the bath-guest in the nose", he continued. When he had sent him off, a true torrent of hatred started against him, he said.'

(A2) Man kann den alten Biestern nicht trauen, ich hab das schon gehabt, dass sie mir ins Bein gebissen haben. that they me.DAT in-the leg bitten have C2 (ZW--_E_05741_SE_01_T_01; 20.09.13) 'You cannot trust these old beasts, I remember times when they bit me in the leg.'

(A3) Es gab heute schon einen kleinen Erfolg, als ich die beiden aus dem Käfig geholt habe und sie mit Hirse gefüttert hab. Ich habe erst dem Hahn die Hirse hingehalten, dann kam die Henne und wollte da auch ran, damit sie ihren Willen kriegt, hat sie mir in die Hand gebissen. so-that she her will gets has she me.DAT in the hand bitten. Das tat echt ziemlich weh, ich hab aber durchgehalten.

C3 (http://www.vogelforen.de/archive/index.php/t-48432.html, accessed March 2014) 'There was some minor success today, when I took both out of the cage and fed them with sorghum. First, I offered the sorghum to the rooster, then the hen approached and wanted to get close, in order to get her way, it [the hen] bit me in the hand. It hurt quite a lot, but I got through it.'

Schlagen 'hit'

(A4) "Erstmals habe ich mit links das Los gezogen.

Mein Sohnhatte mir vor der Abreise dreimal auf die Hand geschlagen", my son had me.DAT before the departure three-times on the hand hit berichtete Leipold.

C1 (M99 Mannheimer Morgen 1999)

" "For the first time, I drew the ticket with my left hand. My son had hit me on the hand three times before the departure", Leipold reported.'

(A5) Und da hat mich ein Ästchen getroffen, das war nicht dicker wie ein Bleistift.

Hat mir auf den Kopf geschlagen.

has me.DAT on the head hit C2 (ZW--_E_01709_SE_01_T_01; 28.10.13)

'And then a twig that was no thicker than a pencil hit me. Hit me on the head.' 
(A6) Mein Sohn (16 Monate), hat seit etwa 3 Wochen die Angewohnheit, mich zu hauen, wenn ihm irgendwas nicht passt. Ich hab schon die verschiedensten Dinge ausprobiert: ich habe getan, als würde ich weinen,

ich hab ihm auf die Hand geschlagen,

I have him.DAT on the hand hit

ich hab ihn geschimpft - es nützt alles nichts.

C3 (http://www.rund-ums-baby.de/forenarchiv/erziehung/Mama-hauen_11937.htm, accessed March 2014)

'For about three weeks, my son (16 months) has had the habit of hitting me, whenever something does not suit him. I have tried all kinds of things: I have pretend-cried, I have hit him on the hand, I have scolded him nothing is of any use.'

Treten 'kick, step'

(A7) Nun ist der Zwölfjährige am Wort. Er und sein Freund werden für den Überfall nicht bestraft: Sie sind zu jung - aber sie sind auch sehr brutal. "Die Frau hat Hilfe geschrien", erzählt der Bub. "Ich habe an ihrer Handtasche gezogen,

ein anderer hat ihr in den Magen getreten."

an other has her.DAT in the stomach kicked

Die 100 Schilling Beute haben sich alle drei geteilt.

C1 (K00 Kleine Zeitung 2000)

'Now, the twelve-year-old speaks. He and his friend will not get punished for the attack. They are too young but they are very brutal. "The woman cried for help", the boy tells, "I pulled on her purse, one of the others kicked her in the stomach." The loot of 100 Schilling was shared among the three of them.'

(A8) Und dann sind sie ja dickfällig,

wenn die dir auf den Fuß treten,

when they you.DAT on the foot step

die heben das Bein nicht wieder hoch, nicht. $\quad$ C2 (ZW--_E_04548_SE_01_T_01; 02.10.13)

'And they are stubborn, you know, when they step on your foot, they won't remove their leg again.'

(A9) $H i$,

mein Großer hat mir beim Wickeln auch leider oft in den Bauch getreten,

my big-one has me.DAT while changing too unfortunately often in the belly kicked

als ich mit Nr.2 ss war. Ist aber nix passiert, das Baby ist ja durchs Fruchtwasser geschützt.

C3 (http://www.rund-ums-baby.de/forenarchiv/schwanger-wer-noch/Meine-Tochter-2-Jahre-hat-mir-in-denbauch-getreten_72607.htm, accessed March 2014)

'Hi, I am sorry to say that, when I was pregnant with number 2, my oldest, too, often kicked me in the belly when I was changing him. Nothing happened, though, because babies are protected by the amniotic fluid.'

(ii) External possession construction with accusative possessor: EPC_ACC

Beißen 'bite'

(A10) Ello berichtete später, Baader sei gewalttätig geworden, habe sie sogar einmal in die Nase gebissen, have her.ACC even once in the nose bitten um zu verhindern, dass sie ihn verlässt.

C1 (BRZ08 Braunschweiger Zeitung 2008) 'Later Ello reported that Baader was violent, and that he even bit her in the nose once in order to keep her from leaving him.'

(A11) biss benni ihn vor wut $\underline{i n} \underline{\text { den }} \underline{\text { po }}[\ldots]$ bit benni him.ACC with rage in the buttocks C2 (FOLK_E_00002_SE_01_T_01, 20.09.13) 'Benni bit him with rage in the buttocks.' 
(A12) Hallo

bin neu hier und muss gleich mein Problem los werden...

Mein kleiner Pascha (3 Monate alter Jack-Russell-Terrier) hat mich gestern in die Nase gebissen. my little Pascha (3-month-old Jack Russell Terrier) has me.ACC yesterday in the nose bitten.

Zuerst haben wir wie immer total lieb miteinander gespielt, wobei er dabei auch manchmal recht wild wird [...], aber das ist doch normal bei so einem jungen Hund, oder?

C3 (http://www.dogforum.de/hilfe-mein-hund-hat-mich-in-die-nase-gebissen-t57915.html, accessed

March 2014)

'Hello, am new here and have to share my problem right away...my little Pascha (3-month-old Jack Russell

Terrier) bit me in the nose yesterday. First we played nicely as always, though he sometimes gets quite rough when we do that $[\ldots]$, but that's normal for such a young dog, isn't it?'

\section{Schlagen 'hit'}

(A13) Dies sei sinnvoll gewesen, weil der Elfjährige im Unterricht Daumen gelutscht hätte. Schläge habe es aber nie gegeben. Der Richter am Weißenburger Amtsgericht glaubte der Aussage des Schülers.

Dieser hatte angegeben, der Lehrer habe ihn mit dem Stock auf die Hand geschlagen.

This-one had declared the teacher have him.ACC with the stick on the hand hit

C1 (NUN06 Nürnberger Nachrichten 2006)

'This made sense, he said, because the eleven-year-old had sucked his thumb during class. But, allegedly, there were never been any beatings. The judge of the local court of Weißenburg believed the testimony of the student. The latter had declared that the teacher hit him on the hand with the stick.'

(A14) Und einmal hat mich die vierjährige Tochter wie zum Spaß auf die Hand geschlagen and once has me.ACC the four-year-old daughter like for fun on the hand hit

$$
\text { C2 (IS--_E_00135_SE_01_T_01; 24.09.13) }
$$

'And once, the four-year-old daughter slapped me on the hand for the fun of it.'

(A15) Abends auf der Couch sagt unser Sohn plötzlich,

dass der Vater eines anderen Kindes ihn ins Gesicht geschlagen hat.

that the father of another child him.ACC in.the face hit has

Wir konnten es erst nicht glauben (welcher Erwachsene macht sowas), aber er hat es mehrmals bestätigt und gezeigt. Heute im Kindergarten bin ich auf diesen Vater getroffen und habe ihn vor der Erzieherin gefragt,

$o b$

er gestern mit seiner Hand meinen Sohn im Gesicht getroffen hat, er bejahte.

C3 (http://www.forum.jurathek.de/archive/index.php/t-7016.html?s=62baa77375bf4a7f75f358f07a4cd95a,

accessed March 2014)

'In the evening, on the couch, our son suddenly said that the father of another child hit him in the face. First, we could not believe it (which adult does do such a thing), but he confirmed it several times, and showed us. Today in Kindergarten I met this father and asked him in front of the nanny, whether he touched my son's face with his hand yesterday, he confirmed it.'

Treten 'kick, step'

(A16) Nach einem erneuten Tritt gegen das Rad habe der 17-Jährige ihn geschlagen, woraufhin er zurückgeschlagen habe. Noch einmal habe er zugeschlagen,

nachdem der 17-Jährige seine Freundin in den Bauch getreten habe. after the 17-year-old his.ACC grirlfriend in the stomach kicked have

C1 (BRZ09 Braunschweiger Zeitung 2009)

'After another kick against the bicycle, the 17-year-old beat him, he said, whereupon he hit back. He struck once more, he said, after the 17-year-old had kicked his girlfriend in the stomach.' 
(A17) Ich will ihn nicht auf den Fuß treten!

I want him.ACC not on the foot step C2 (ZW--_E_03190_SE_01_T_01;02.10.13)

'I don't want to step on his foot!'

(A18) Der Angeklagte: "Da bin ich sauer geworden und habe ihr eine geklatscht. Getreten habe ich sie aber

nicht.” Der Zeuge jedoch, der damals zufällig in der Nähe stand, berichtete:

"Er hat sie in den Bauch getreten.

he has her.ACC in the belly kicked

Sie ist zurückgetaumelt. Dann hat er ihr noch eine Ohrfeige verpasst. Sie ist zusammengeklappt. Man konnte sehen, dass Schmerzen da waren."

C3 (http://www.derwesten.de/staedte/bochum/ehefrau-in-den-bauch-getreten-haft-auf-bewaehrung-id3490456.html,

accessed March 2014)

'The accused: "Then I got mad and slapped her. I did not kick her, though." The witness, however, who at that time happened to be nearby, reported: "He kicked her in the belly. She fell back. Then, he gave her a slap in the face on top of it. She collapsed. You could see that there was pain.",

\section{(iii) Internal possession construction: IPC (C3 only)}

Beißen 'bite'

(A19) Ich wollte mal meinen Otto mit ner weißen Futtermaus füttern. Naja, anscheinend hatte die Maus aber was gewittert und ist mir plötzlich auf den Arm gesprungen, so schnell konnt ich gar net gucken. Otto hat nurMaus gerochen und die Bewegung gesehn und einfachmal in meine Hand gebissen. Otto has only mouse smelled and the movement seen and simply just in my hand bitten Aber er hat sofort wieder losgelassen, als er gemerkt hat, dass er mich hatte.

(http://www.nexusboard.net/sitemap/12937/beissen-t2282/, accessed January 2014) 'One time, I wanted to feed my Otto with a white mouse for food. Well, it seems the mouse noticed something and suddenly jumped on my arm, more quickly that I could look. Otto just smelled mouse and saw the movement and simply bit into my hand. But he let go again at once when he realized he got me.'

Schlagen 'hit'

(A20) Weil ihr Deutsch für ausführliche Erklärungen aber noch nicht gut genug ist, habe sie immer auf ihren KölnPass gezeigt, den sie der Kontrolleurin aushändigen musste.

Als Reaktion habe die KVB-Mitarbeiterin mit dem Kontrollgerät auf ihre Hand geschlagen. as reaction have the KVB-worker with the control-device on her hand hit "Ich habe mich so schlecht gefühlt, hatte Schmerzen und habe nur noch geweint." Sie habe sich ausgeliefert und alleingelassen gefühlt.

(http://www.ksta.de/koeln-uebersicht/kvb-diskriminierung-in-der-bahn, 16341264,16213250.html, accessed January 2014)

'Because her German is not yet good enough for detailed explanations, she said she kept pointing to her Cologne card, which she had to hand over to the controller. As a reaction to that, the KVB-officer hit her hand with the control device. "I felt so miserable, had pain and did nothing but cry." She felt she was set-up and left alone.' 


\section{Treten 'kick'}

(A21) Also... Die kleine Maus hat heute Nacht die ganze Zeit in meinen Magen getreten. well... the little mouse has today night the whole time in my stomach kicked Inzwischen ist dieser natürlich ziemlich beleidigt und steinhart. Hab schon ein Magnesium genommen in der Hoffnung dass er sich entkrampft. Tut sich aber nix. Was kann man dagegen tun?

(http://www.parents.at/forum/showthread.php?t=544687\#.Us_UzLSoC1w, accessed January 2014) 'Well... the peewee kicked in my stomach constantly tonight. Meanwhile, it [my stomach] is of course rather offended and rock-hard. I have already taken magnesium hoping the cramps would go away. But nothing is happening. What can be done about that?'

\section{(iv) Doubly-marked possession construction: DMPC_DAT (C3 only)}

\section{Beißen 'bite'}

(A22) Aber: sie hat wohl ein Problem mit meinem Freund das ich (noch) nicht verstehe. Angefangen hat es, als wir eines Abends auf der Couch lagen und er mich gekitzelt bzw. liebevoll geärgert hat. Ich hab natürlich gelacht und mich "gewehrt". Erst hat Lolita gebellt und geknurrt und danach ist sie auf die andere Seite der Couch und hat ihm in seine Hand gebissen (aber nicht fest). and has him.DAT in his hand bitten (but not strongly).

Danach saß meine Hündin in ihrem Körbchen und hat ihn immer angeknurrt sobald er sie angesprochen hat. (http://www.dogforum.de/hundin-knurrt-und-schnappt-nach-meinem-freund-t151643.html, accessed January 2014)

'But: she obviously has a problem with my boyfriend that I do not (yet) understand. It started when we lay on the couch one evening, and he tickled or rather teased me affectionately. I laughed, of course, and "defended" myself. At first, Lolita barked and growled and after that she moved to the other side of the couch and bit him in his hand (but not strongly).'

Schlagen 'hit'

(A23) Auf dem Weingut habe ich dann meine erste giftige Spinne gesehen, eine Redback-Spider.. ich habe erst gemerkt, dass sie tödlich ist, als sie mir schon über die Hand gelaufen ist $: D$

Lori, unsere Chefin hat dann erschrocken aufgeschrien und mir auf meine Hand geschlagen! Lori our boss has then in-shock screamed and me.DAT on my hand hit

Jetzt gehe ich das ganze etwas vorsichtiger an :)

(http://philipboehm.blog.de/2012/11/28/heile-heile-segen-p-15255558/, accessed January 2014)

'On the vineyard, I then saw my first poisonous spider, a redback spider. I only realized it was lethal when it already scurried over my hand. Lori, our boss screamed in shock and hit me on my hand. Now, I'm going about things a bit more carefully.'

Treten 'kick, step'

(A24) Aua! Mein Pferd ist ein richtiges Trampeltier!

Ist mir dieses Riesenrindvieh heut mittag tatsächlich auf meine Zehen getreten, is me.Dat that huge-cow this noon indeed on my toes stepped und lieb wie er ist, hat er "nur" den kleinen Zeh erwischt. Das tut immer noch saumäßig weh! Hatte gehofft, dass es im Laufe des Tages wieder besser wird, aber es tut immer noch genauso weh. *heul*! Kann der nichtmal jemand anderen auf den Zehen rumlatschen, warum denn immer mir? LG Nicole

(http://community.fressnapf.de/forum/thema/130152/2119, accessed January 2014) 'Ouch! My horse is a true camel! That stupid horse actually stepped on my toes today, and, friendly, as he is, he only got my pinky toe. It still hurts like crazy. I had hoped that in the course of the day it would get better, but it still hurts like before. *Cry*! Can't he walk around on someone else's toes, why must it be mine? Love, Nicole' 


\section{(v) Doubly marked possession construction: DMPC_ACC (C3 only)}

Beißen 'bite'

(A25) Wie weit dies gehen kann (und wie wichtig eine Hundehaftpflicht auch für den liebsten Hund ist) wird an einem Urteil des Oberlandesgerichts Celle ersichtlich. Ein Schäferhund befand sich in der Obhut des Tierarztes.

Beim Aufwachen aus der Narkose hat er diesen in seine Hand gebissen. when coming-to from the anaesthesia has he this-one.ACC in his hand bitten Dieser Tierarzt verklagte die Hundehalterin auf Schmerzensgeld sowie Schadensersatz im sechstelligen Bereich, mit Erfolg. Ein umstrittenes Urteil, mit welchem wir als Hundehalter nicht gerechnet hätten.

(http://www.im-vergleich-24.de/hundehaftpflicht/, accessed January 2014) 'A sentence of the high court Celle shows to what length this can go (and how important pet insurance is even for the most friendly dog). A German shepherd was in the care of a vet. When coming to from anesthesia, it bit him in his hand. The vet sued the dog owner for pain and suffering as well as damages for a six-figure sum, and he was successful. A controversial sentence, which we as dog owners would not have expected.'

\section{Schlagen 'hit'}

(A26) Im Bereich eines Kiosks trafen die Einsatzkräfte auf eine eingeschüchterte 21-jährige Essenerin. Diese bestätigte, dass sie durch eine männliche Person grundlos angegriffen wurde.

Der Mann habe sie dabei mit der Faust in ihr Gesicht geschlagen.

the man have her.ACC in-the-process with the fist in her face hit

Bundespolizisten nahmen daraufhin einen 30-jährigen Obdachlosen, der durch Bahnmitarbeiter festgehalten wurde, vorläufig fest.

(http://www.presseportal.de/polizeipresse/pm/70116/2566943/bpold-sta-30-jaehriger-schlug-grundlos-zujunge-essenerin-im-gesicht-verletzt-bundespolizei-nimmt, accessed January 2014) 'In the surroundings of the convenience store, the task force met a frightened 21-year-old woman from Essen. She confirmed that she had been attacked by a male person for no reason. During the attack, the man hit her in the face with his fist, she said. After that, federal police officers arrested a 30-year-old homeless person who had been held up by a railway officer.'

Treten 'kick', step'

(A27) Mehr oder weniger knapp 50 Sekunden vor Spielende, bei einem ein Punkt-Rückstand der DJK und Ballbesitz für Ludwigsstadt, bekam Raum, der seinen Körper nicht schnell genug zur Seite bekam und so etwas zu spät die Auslinie zu machte, wo TSV-Akteur Mohler vorbeiziehen wollte, ein witzloses unsportliches Foul von einen der beiden Schiedsrichter angehängt, mit der Begründung,

er hätte ihn auf seinen Fuß getreten.

he had him.ACC on his foot stepped

(http://www.djk-bamberg-basketball.de/newsartikel.php?Bericht=792, accessed January 2014)

'More or less 50 seconds before the end of the game, the DJK trailing by one point and Ludwigsstadt having possession, a pointless unfair foul was called against Raum, who had not managed to move aside quickly enough and thus covered the sideline a little too late, where TSV-player Mohler wanted to pass him. The referee justified it by saying that he had stepped on his foot.' 